\title{
Functionalized coconut husks for rhodamine-B dye sequestration
}

\author{
Olugbenga Solomon Bello ${ }^{1,2} \cdot$ Kayode Adesina Adegoke ${ }^{3}$. Samuel Oluwaseun Fagbenro \\ Olasunkanmi Seun Lameed ${ }^{1}$
}

Received: 4 October 2018 / Accepted: 1 October 2019 / Published online: 17 October 2019

(c) The Author(s) 2019

\begin{abstract}
This study investigates the efficacy of acid activated coconut husk (CHA) for the removal of rhodamine-B (Rh-B) dye from aqueous solutions. The CHA prepared was characterized using various techniques: SEM, FTIR EDX, Boehm titration and $\mathrm{pH}_{\mathrm{pzc}}$, respectively. The effects of different operational parameters including initial concentration, contact time and solution temperatures were examined. Kinetic data for Rh-B dye adsorption onto CHA fitted best to pseudo-second-order kinetic model considering the correlation regression $\left(R^{2}\right)$ and the sum of squares of error values. Adsorption data were fitted to Langmuir, Freundlich, Dubinin-Radushkevich and Temkin isotherm models. Langmuir isotherm was the most fitted among all the models used with maximum monolayer sorption capacity of $1666.67 \mathrm{mg} \mathrm{g}^{-1}$ and the highest regression value of 0.99 indicating that CHA has greater affinity for Rh-B dye adsorption due to increased pore development via acid activation. Thermodynamic studies revealed an endothermic adsorption process with the $\Delta H^{0}$ value of $62.77 \mathrm{~kJ} \mathrm{~mol}^{-1}$. Spontaneity was ascertained based on the negative values of $\Delta G^{\mathrm{o}}$ (ranging from $-26.38 \mathrm{~kJ} \mathrm{~mol}^{-1}$ to $-20.93 \mathrm{~kJ} \mathrm{~mol}^{-1}$ ). The positive value of $\Delta S^{0}\left(0.276 \mathrm{~kJ} \mathrm{~mol}^{-1} \mathrm{~K}^{-1}\right)$ suggests increased randomness that exists between $\mathrm{CHA}$ and Rh-B dye. Cost analysis results

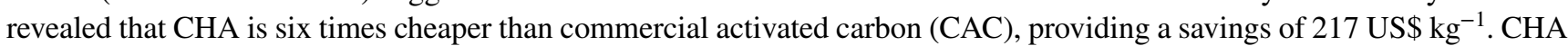
adsorbent was found to be suitable for Rh-B dye removal from aqueous solution.
\end{abstract}

Keywords Rhodamine-B dye $($ Rh-B) $\cdot$ Coconut Husk $\cdot$ Isotherm $\cdot$ Kinetics $\cdot$ Thermodynamics

\section{Introduction}

Although two-thirds of the Earth form the hydrosphere, the availability of fresh and quality water decreases as urbanization is globally encouraged. The essentiality of quality water to all living organisms cannot be over-emphasized (Namasivayam and Sangeetha 2006; Parab et al. 2009; Gupta et al. 2010; Khan et al. 2011; Wang and Chu 2011; Jain et al. 2015; Rani et al. 2017). Since water is a universal solvent, it

Olugbenga Solomon Bello

osbello06@gmail.com

Kayode Adesina Adegoke

kwharyourday@gmail.com

1 Department of Pure and Applied Chemistry, Ladoke Akintola University of Technology, P.M.B. 4000, Ogbomoso, Oyo State, Nigeria

2 Department of Physical Sciences, Industrial Chemistry Programme, Landmark University, Omu-Aran, Nigeria

3 Department of Chemistry, University of Pretoria, Pretoria 0002, South Africa readily dissolves any water-soluble substance either solutes or pollutants; therefore, the quality of water becomes altered or contaminated (Namasivayam et al. 2007; Sureshkumar and Namasivayam 2008; Hayeeye et al. 2014; Patel 2018; Sydorchuk et al. 2019). Solubility property of dyes makes them one of the common water contaminants (Yadav et al. 2013; Bello et al. 2015; Goyal et al. 2015; Ojedokun and Bello 2017). Colorful materials are eye catchers, so manufacturing industries employ more of commercially available synthetic dyes that are toxic than non-toxic natural dyes to color their products. These dyes are used widely in paints, leather, plastics, paper and textile industries (Thirumalisamy and Subbian 2010; Bello et al. 2015). The stability of the ecosystem is affected due to effluents discharged from different industries gaining access into water bodies (Hameed et al. 2007; Tan et al. 2008). Furthermore, majority of these dyes pose allergic reactions, dermatitis and skin irritations which in addition lead to genetic mutations and cancer in humans as a result of their toxic nature (Adegoke and Bello 2015; Bello et al. 2015, 2017a; Ahmad et al. 2016; Adeyemo et al. 2017); industrial effluents or domestic sewage with the 
small quantity of dye concentration have severe effects on aquatic organisms owing to its toxicity and ability to inhibit penetration of light (Adegoke and Bello 2015).

Rhodamine-B (Rh-B) dye is an amphoteric dye; though often listed as a basic dye, to the class of xanthene dye, it is noted to be harmful when swallowed, with acute oral toxicity (Namasivayam and Kanchana 1992; Wilhelm and Stephan 2007; Hema and Arivoli 2007; Vasu 2008; Parab et al. 2009; Li et al. 2010; Gupta et al. 2012; Ashkarran et al. 2013; Gong et al. 2013; Suc and Kim Chi 2017; Cheng et al. 2017; Singh et al. 2017; Adegoke et al. 2019). Rh-B dye causes serious eye damage or irritation, hazardous to aquatic environment with long-term effects (Hema and Arivoli 2007; Sureshkumar and Namasivayam 2008; Sadasivam et al. 2010; Gupta et al. 2012; Inyinbor et al. 2015; Dahri et al. 2016; Dharmendirakumar et al. 2016; Fu et al. 2016; Inyinbor et al. 2016; Kooh et al. 2016; Goswami and Phukan 2017; Iqbal et al. 2017; Adegoke et al. 2019). Consequently, water treatment is one of the global campaign exercises, which demands scientific investigation. Several techniques adopted in wastewater treatment are: oxidative techniques, precipitation, reverse osmosis, ion exchange, ozonation, ultrafiltration, flocculation, coagulation, etc. (Namasivayam and Sangeetha 2006; Parab et al. 2009; Gupta et al. 2010; Khan et al. 2011; Wang and Chu 2011; Adegoke and Bello 2015; Jain et al. 2015; Rani et al. 2017). Among different conventional methods used for water treatment, adsorption process by activated carbon (AC) remains one of the sustainable approach to removing various pollutants (Deschaux et al. 2011; Adegoke and Bello 2015; Bello et al. 2015). This method is not complex for an average skilled technician to master and also requires only limited resources; hence, industries can adopt this noble method (Kooh et al. 2016). Commercial activated carbon (CAC), used conventionally for adsorption processes and other varieties of application, is scare, expensive and non-renewable (Namasivayam and Sangeetha 2006; Parab et al. 2009; Gupta et al. 2010; Khan et al. 2011; Wang and Chu 2011; Jain et al. 2015; Rani et al. 2017). The need for suitable replacements opens an opportunity for the effective use of agricultural wastes as adsorbent, and some of these largely available and inexpensive adsorbents have been reported for dye removal including cocoa pod husk (Olakunle et al. 2018) Moringa oleifera seed pod (Bello et al. 2017b), scrap tires (Li et al. 2010) Raphia hookerie fruit epicarp (Inyinbor et al. 2016), rambutan seed (Ahmad et al. 2016), Durian seed (Ahmad et al. 2015), sugarcane bagasse (Saad et al. 2010), bengal gram seed husk (Somasekhara Reddy et al. 2017), walnut shell (Ojo et al. 2019) among others.

Coconut husk (Cocos nucifera), an agricultural waste product from the coconut tree, is widely grown worldwide, for consumption, beautification and/or for erosion control. The husk is the large covering part of the fruit at the point of harvest. After consuming the white edible part of the fruit, the outer cover is thrown away, constituting a serious nuisance to the environment. However, to salvage the environment from the resulting mess, a non-conventional adsorbent is made from these coconut husks, thus converting these wastes into useful adsorbents. Activated carbon is extensively used adsorbent in many industrial processes because it composes of microporous and mesoporous structures and high surface areas (Mittal et al. 2010; Jawad et al. 2016; Rashid et al. 2018). Currently, research into finding sustainable alternative to replace $\mathrm{CAC}$ has been given more attention (AlOthman et al. 2014; Adegoke and Bello 2015; Bello et al. 2017a). Exploring this sustainable and eco-friendly adsorbent offers numerous usages for future industrial scale-up applications (Bello et al. 2017a; Ojedokun and Bello 2017). The costs of ACs derived from biomaterials and agricultural wastes are realistically lower in comparison with CACs (Ahmad et al. 2016; Adegoke et al. 2017; Bello et al. 2017a, c). In this study and for the first time, coconut husk was modified using orthophosphoric acid and its capability to remove rhodamine-B dye from simulated water was tested. Adsorption kinetic and batch equilibrium studies were employed to investigate the kinetics, isotherms, and kinetic data of the adsorption process. Adsorption mechanisms and thermodynamic parameters governing the sorption of Rh-B dye onto the modified coconut husk were studied.

\section{Materials and method}

\section{Adsorbent pre-treatment and activation}

Coconut husks were obtained in Ogbomoso, Oyo State, Nigeria, and then washed thoroughly with clean tap water. To remove the suspended impurities, the husks were further washed with distilled water and double-distilled, respectively. The husk's fiber dust and cuticle were mashed and sieved using a different mesh-sized sieve. Particle size of $120 \mu \mathrm{m}$ was selected for characterization prior experimentation. Twenty-five grams of the powdered sample was weighed, activated with orthophosphoric acid and then heated in $500 \mathrm{~mL}$ of $0.3 \mathrm{M} \mathrm{H}_{3} \mathrm{PO}_{4}$ until paste was formed. The resulting paste was transferred into an evaporating dish and then allowed to cool. The cooled paste was carbonized in a furnace at $350{ }^{\circ} \mathrm{C}$ for $90 \mathrm{~min}$ to establish the reaction between the carbon and the activating agent in breakdown of the lignocellulosic materials at this temperature. After cooling, the resulting ACs were then washed with distilled water to obtain a $\mathrm{pH}$ 6.8. Activated coconut husk (CHA) was then dried at a temperature of $105^{\circ} \mathrm{C}$ for the purpose of removing the moisture content. The CHA sample is kept for further use in an airtight container. 


\section{Adsorbate preparation}

$1000 \mathrm{mg} \mathrm{L}^{-1}$ of stock solution containing rhodamine-B (Rh-B) dye was prepared by dissolving an accurately weighed $1 \mathrm{~g}$ of analytically grade $\mathrm{Rh}-\mathrm{B}$ in $1000 \mathrm{~cm}^{3}$ of double distilled water. Other concentrations for batch equilibrium studies were prepared from the stock by serial dilution method.

\section{Characterization of adsorbent}

\section{Fourier transform infrared (FTIR)}

The FTIR spectra of both raw (CHR) and acid activated coconut husk (CHA) were analyzed using FTIR-2000 with $\mathrm{KBr}$ disk technique (Shimadzu Model IRPrestige-21 Spectrophotometer). The spectroscopic analyses enable the study of the surface chemistry of CHR and CHA powder. The FTIR spectra revealed the detail about the characteristics functional group(s) on the surfaces of both raw (CHR) and activated (CHA).

\section{Scanning electron micrograph (SEM)}

This is a versatile imaging technique based on electron-material interaction, capable of producing images of the sample surface. The principle is based on the fact that an electron beam bombards the surface of the sample to be analyzed which thereby re-emits certain particles; the electrons then interact with atoms in the sample, thus providing quantitative and qualitative information pertaining to particle morphology and surface appearance of samples. Various detectable signals contain specific information concerning the samples' surfaces topology and compositions which are analyzed by a range of detectors to give three-dimensional image(s). This technique was employed to study the surface characteristics and the morphological feature of the adsorbent materials for both the raw and the activated samples.

\section{Energy-dispersive X-ray (EDX)}

The EDX analysis was carried out on both the raw and activated coconut samples, to determine the component elements before and after acid activation. Each elemental analysis line(s) spectra correspond to specific element composition. The intensities of the characteristics' line are proportional to the element concentration; these analyses are quantitative in nature.

\section{Oxygen-containing functional group(s) determination}

Functional groups containing oxygen were determined using the Boehm titration analysis method (Boehm 2002; Ekpete and Horsfall 2011). Four portions of $1.0 \mathrm{~g}$ each of the raw and activated samples were kept in contact with $10-15 \mathrm{~mL}$ separate solution of $0.1 \mathrm{M} \mathrm{NaHCO}_{3}, 0.05 \mathrm{M} \mathrm{Na}_{2} \mathrm{CO}_{3}$ and $0.1 \mathrm{M} \mathrm{NaOH}$ for an acidic group composite and $0.1 \mathrm{M} \mathrm{HCl}$ for a basic group composite, respectively, at an ordinary temperature for $48 \mathrm{~h}$. Afterward, the resulted solutions were back-titrated with $0.1 \mathrm{M} \mathrm{HCl}$ for acidic and $0.1 \mathrm{M} \mathrm{NaOH}$ for basic groups. The numbers and types of acidic sites were calculated using our previous procedure (Bello et al. 2017b, c).

\section{$\mathrm{pH}$ and point of zero charge $\mathrm{pH}\left(\mathrm{pH}_{\mathrm{pzc}}\right)$ determination}

To determine $\mathrm{pH}_{\mathrm{pzc}}$ of the adsorbent, $0.05 \mathrm{~g}$ of activated coconut husk (CHA) was added to the $100 \mathrm{~mL}$ solution of $0.1 \mathrm{M} \mathrm{NaCl}$ of a known initial $\mathrm{pH}$; the $\mathrm{pH}$ was adjusted with $\mathrm{NaOH}$ or $\mathrm{HCl}$. The sample holder was corked and placed in a shaker, made to be agitated at $250 \mathrm{rpm}$ for $24 \mathrm{~h}$. The final $\mathrm{pH}$ was then measured. In order to determine the $\mathrm{pH}_{\mathrm{pzc}}$, a graph of $\mathrm{pH}$ difference, $\Delta \mathrm{pH}$ (final $\mathrm{pH}$ - initial $\mathrm{pH}$ ) was plotted against the initial $\mathrm{pH}$. The $\mathrm{pH}_{\mathrm{pzc}}$ exists when $\mathrm{pH}$ does not change upon a contact with the adsorbent(s).

\section{Batch adsorption experiments}

Rhodamine-B dye removal was investigated using the batch technique at various temperatures ( $303 \mathrm{~K}, 313 \mathrm{~K}$ and $323 \mathrm{~K}$ ). The effects of operational parameters such as initial dye concentration, contact time, adsorbent dose and solution temperatures were studied. The adsorbent dosage used throughout the adsorption process was $0.1 \mathrm{~g}$ of CHA. Adsorption process was studied at five initial dye concentrations: 200 , 400, 600, 800 and $1000 \mathrm{mg} \mathrm{L}^{-1}$, respectively. The process was carried out in a water bath shaker and allowed to proceed to equilibrium at $120 \mathrm{~min}$. Five sets of $100-\mathrm{mL}$ Erlenmeyer flasks containing the mixture of $0.1 \mathrm{~g}$ of the sample and the Rh-B dye solution of different initial dye concentrations were carefully arranged in the shaker and then agitated at $120 \mathrm{rpm}$. The shaker used is a thermostatic water bath shaker filled with water to the level of the arranged flask's solution, so as to maintain a uniform temperature to that of the shaker at specified temperatures until equilibrium was reached. Withdrawals of sample solutions were done at predetermined time intervals for the determination of residual concentrations using a UV-Vis spectrophotometer at the maximum wavelength of $554 \mathrm{~nm}$. Amount of Rh-B dye uptake and Rh-B dye percentage removal at equilibrium were calculated using Eqs. 1 and 2, respectively:

$q_{\mathrm{e}}=\frac{\left(C_{\mathrm{o}}-C_{\mathrm{e}}\right) V}{m}$ 
$\%$ removal $=\left[\frac{\left(C_{\mathrm{o}}-C_{\mathrm{e}}\right)}{C_{\mathrm{o}}}\right] \times 100 \%$

where " $C_{\mathrm{o}}$ and $C_{\mathrm{e}}$ are respective initial dye concentration and equilibrium concentration $\left(\mathrm{mg} \mathrm{L}^{-1}\right), V$ is the volume of solution $(\mathrm{mL}), m$ is the mass of adsorbent $(\mathrm{g}), Q_{\mathrm{e}}$ is the amount of dye adsorbed $\left(\mathrm{mg} \mathrm{g}^{-1}\right)$ ".

However, the interaction between the adsorbate and the adsorbent was analyzed via four isotherm models: Freundlich, Langmuir, Dubinin-Radushkevich (D-R) and Temkin models. Adsorption kinetic study offers useful information on the pathways and reaction mechanisms of the reaction as it relates rate of the adsorption with the adsorbate concentration in the solution. Kinetic of adsorption of Rh-B dye onto CHA was studied via pseudo-first-order (PFO), pseudo-second-order (PSO), Elovich and intraparticle diffusion (IPD) models. Isotherm and kinetics parameters for adsorption of Rh-B dye onto CHA are presented in Table 1.

\section{Kinetic model fitness test}

In addition to the correlation regression $\left(R^{2}\right)$ value common to all the kinetic models, the model fitness or applicability can be tested by using the sum of error squares (SSE, \%). Adsorption rate of Rh-B dye molecule onto CHA was determined at various initial dye concentrations. However, all kinetic models employed for the kinetic studies of the adsorption processes were verified by SSE (\%) calculated using Eq. 14:

$\operatorname{SSE}(\%)=\sqrt{\sum \frac{\left(q_{\mathrm{e}, \mathrm{exp}}-q_{\mathrm{e}, \mathrm{calc}}\right)^{2}}{N}}$ where " $N$ is the number of data points, $q_{\mathrm{e}, \text { exp }}$ and $q_{\mathrm{e}, \text { calc }}$ are the amount of the adsorbed Rh-B-dye, obtained experimentally and by calculation $\left(\mathrm{mg} \mathrm{g}^{-1}\right)$. The lower the value of SSE (\%), the higher $R^{2}$ value, the better the kinetic model fitted" (Bello et al. 2017b).

\section{Adsorption thermodynamic studies}

The changes in Gibbs free energy $\left(\Delta G^{\mathrm{o}}\right)$, enthalpy $\left(\Delta H^{\mathrm{o}}\right)$ and entropy $\left(\Delta S^{\circ}\right)$ are the thermodynamic parameters used as actual indicators for practical applications in this study (Eqs. 15-17). These were used to evaluate the thermodynamics of adsorption at different temperatures under study (303, 313 and $323 \mathrm{~K})$ :

$\Delta G^{\circ}=-\mathrm{RT} \ln K_{\mathrm{L}}$

$\ln K_{\mathrm{L}}=\frac{\Delta S^{\circ}}{R}-\frac{\Delta H^{\circ}}{\mathrm{RT}}$

The values of $\Delta S$ and $\Delta H$ were obtained from the intercept and slope of van't Hoff plot of $\ln K_{\mathrm{L}}$ against $1 / T$. The values of $K_{\mathrm{L}}$ (Langmuir constant in $\mathrm{L} \mathrm{mol}^{-1}$ ) are calculated from the relation $\ln q_{\mathrm{e}} / C_{\mathrm{e}}$ at different solution temperatures ( $303 \mathrm{~K}, 313 \mathrm{~K}$ and $323 \mathrm{~K}$ ), respectively. Arrhenius equation was employed to calculate the adsorption energy of activation which represents the minimum energy needed by the reactants for reaction to occur (Eq. 17):

$\ln K_{2}=\ln A-\frac{E_{\mathrm{a}}}{\mathrm{RT}}$

where $K_{2}$ is the PSO rate constant $\left(\mathrm{g}(\mathrm{mg} \mathrm{h})^{-1}\right), E_{\mathrm{a}}$ is the Arrhenius energy of activation of Rh-B dye adsorption, $\left(\mathrm{kJ} \mathrm{mol}^{-1}\right)$ with A being the Arrhenius factor, $\mathrm{R}$. The plot

Table 1 Adsorption Isotherm and Kinetic Equations

\begin{tabular}{|c|c|c|c|}
\hline Adsorption model & Type & Expression & Refs. \\
\hline \multirow[t]{6}{*}{ Isotherm } & Langmuir & $\begin{array}{l}\frac{C_{\mathrm{e}}}{q_{\mathrm{e}}}=\frac{1}{q_{\mathrm{m}} C_{\mathrm{e}}}+\frac{1}{\mathrm{~K}_{\mathrm{L}} q_{\mathrm{m}}} \\
R_{\mathrm{L}}=\left[\frac{1}{\left(1+K_{\mathrm{L}} C_{\mathrm{o}}\right)}\right]\end{array}$ & Langmuir (1918) \\
\hline & Freundlich & $\ln q_{\mathrm{e}}=\frac{1}{n} \ln C_{\mathrm{e}}+\ln K_{\mathrm{f}}$ & Freundlich (1906) \\
\hline & Temkin & $q_{\mathrm{e}}=B \ln K_{\mathrm{T}}+B \ln C_{\mathrm{e}}$ & Temkin and Pyzhev (1940) \\
\hline & Dubinin-Radushkevich isotherm & $\ln q_{\mathrm{e}}=\ln q_{\mathrm{m}}+\beta \varepsilon^{2}$ & Dubinin (1960) \\
\hline & & $\varepsilon=\mathrm{RT}\left[1+\frac{1}{C_{\mathrm{e}}}\right]$ & Ajemba (2014), Ojedokun and Bello (2017) \\
\hline & & $E=\frac{1}{\sqrt{2 \beta}}$ & \\
\hline \multirow[t]{4}{*}{ Kinetics } & Pseudo-first order & $\ln \left(q_{\mathrm{e}}-q_{\mathrm{t}}\right)=\ln q_{\mathrm{e}}-K_{1}$ & Lagergren (1898) \\
\hline & Pseudo-second order & $\frac{t}{q_{\mathrm{e}}}=\frac{1}{K_{2} q_{\mathrm{e}}}+\frac{1}{q_{\mathrm{e}} t}$ & Ho and McKay (1999) \\
\hline & Elovich & $q_{\mathrm{t}}=\frac{1}{\beta} \ln (\alpha \beta)+\frac{1}{\beta} \ln t$ & Aharoni and Ungarish (1976) \\
\hline & Intraparticle diffusion & $q_{\mathrm{t}}+K_{\mathrm{diff}} t^{1 / 2}+C$ & Weber and Morris (1962) \\
\hline
\end{tabular}


of $\ln K_{2}$ versus $1 / T$ gives a straight line graph with the slope of $-E_{\mathrm{a}} / R$.

\section{Results and discussion}

\section{Characterization of activated carbon prepared}

\section{The FTIR Spectral analysis}

Figure 1 shows the FTIR spectra of raw coconut husk (RCH) (Fig. 1a) and activated coconut husk (CHA) (Fig. 1b). The comparable features of absorption bands for each FTIR spectrum are presented in Table 2. The spectra of both samples revealed the existence of different functional groups with either a disappearance, reduction or broadening of the peaks after the process of acid activation (Fig. 1a). The stretched band width observed at $3433.29 \mathrm{~cm}^{-1}$ was assigned to $\mathrm{O}-\mathrm{H}$ stretching vibration of hydroxyl groups such as hydrogen bonding. The aliphatic $\mathrm{C}-\mathrm{H}$ stretch was observed for the band seen at $2926.01 \mathrm{~cm}^{-1}$. Some major detectable peaks at bandwidths $2376.30 \mathrm{~cm}^{-1}, 1705-1739.79 \mathrm{~cm}^{-1}$ and $1624.06-1618.28 \mathrm{~cm}^{-1}$ were assigned to alkyne group (i.e., $\mathrm{C} \equiv \mathrm{C}$ stretching), carboxylic $\mathrm{C}=\mathrm{O}$ stretching vibrations of lactone, ketone and carboxylic anhydride and $\mathrm{C}=\mathrm{C}$ aromatic rings, respectively. The band observed at $1377.17 \mathrm{~cm}^{-1}$ was attributed to $\mathrm{C}-\mathrm{H}$ stretching alkane or alkyl groups. The disappearance of phenol and ether in CHA samples showed a thermal instability of functional groups (Deschaux et al. 2011; Ahmad et al. 2015).
Fig. 1 FTIR spectra of a raw coconut husk $(\mathrm{RCH})$ and $\mathbf{b}$ activated coconut husk (CHA)
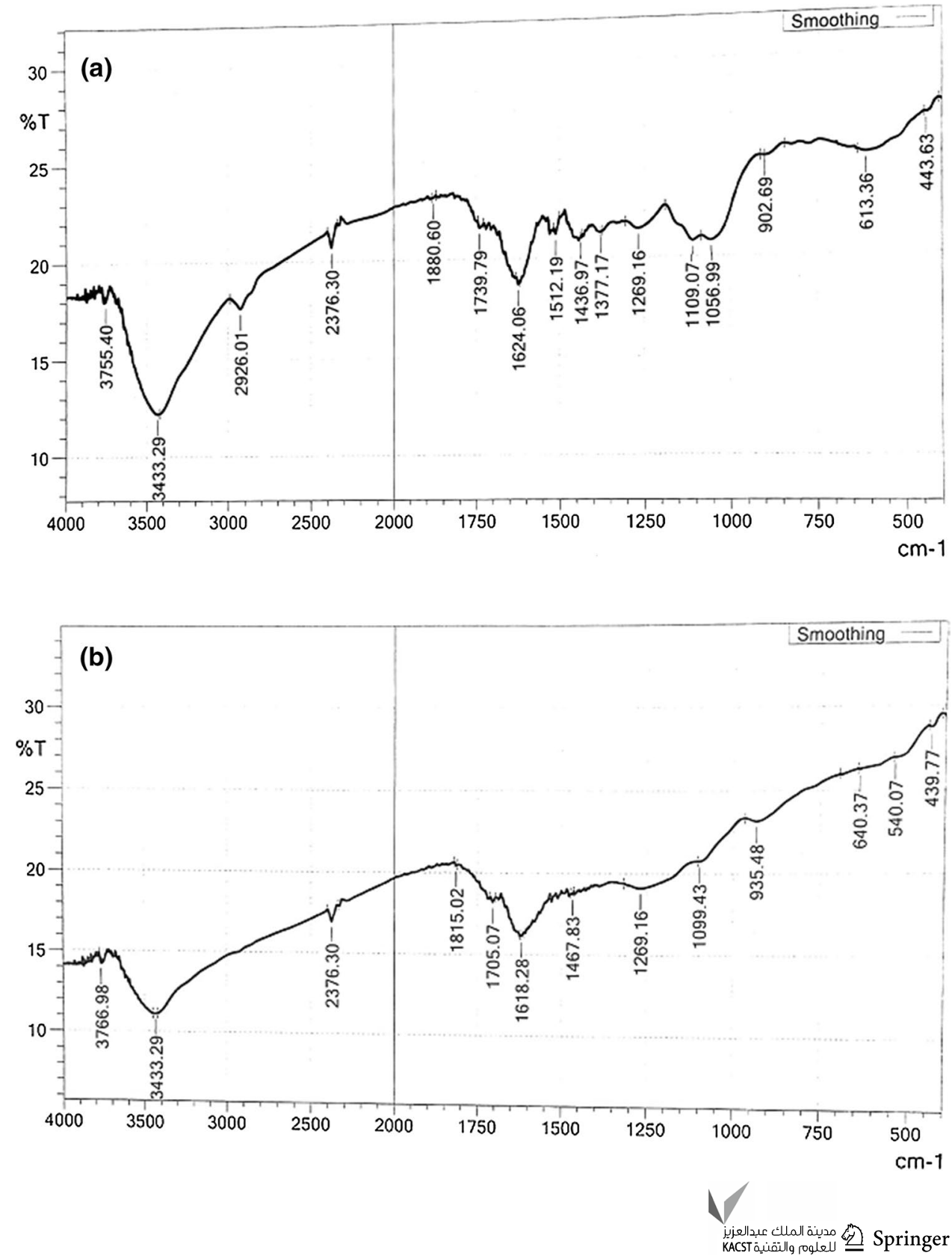


\section{The scanning electron micrograph (SEM)}

The SEM images of CHR and CHA are shown in Fig. 2a, b. It shows clearly that the pores surfaces of CHR (Fig. 2a) were not well developed; this surface morphology hinders the internal penetration of dye molecules, whereas in Fig. 3b, there are formations of several well-developed pores on the CHA (Fig. 2b), owing to the effects of activating agent at high temperature which broke down the lignocellulosic materials followed by volatilization of volatile compound(s) (Bello et al. 2012, 2017c). This demonstrated that $\mathrm{H}_{3} \mathrm{PO}_{4}$ activation leads to creation of well-developed pores on the precursor surfaces, thereby leading to $\mathrm{AC}$ with large porous surface areas and structures. The development
Table 2 FTIR spectrum band assignment for CHR and CHA

\begin{tabular}{lllll}
\hline IR peak & CHR $\left(\mathrm{cm}^{-1}\right)$ & CHA $\left(\mathrm{cm}^{-1}\right)$ & Differences & Band assignments \\
\hline 1 & 3433.29 & 3433.29 & 0 & O-H stretching \\
2 & 2926.01 & - & - & C-H stretching of volatile alkanes \\
3 & 2376.30 & 2376.30 & 0 & C $=\mathrm{C}$ of alkyne \\
4 & 1739.79 & 1705.07 & -34.72 & $\mathrm{C}=\mathrm{O}$ carbonyl bands of ketones \\
5 & 1624.06 & 1618.28 & -5.78 & $\mathrm{C}=\mathrm{C}$ of alkene \\
6 & 1377.17 & - & - & C-H stretching in alkanes or alkyl group \\
7 & 1109.07 & - & - & C-O of esters, ether or phenol group \\
\hline
\end{tabular}

Fig. 2 SEM images of a CHR $(\mathrm{Mag} \times 500)$ and $\mathbf{b} \mathrm{CHA}$ $(\mathrm{Mag} \times 500)$
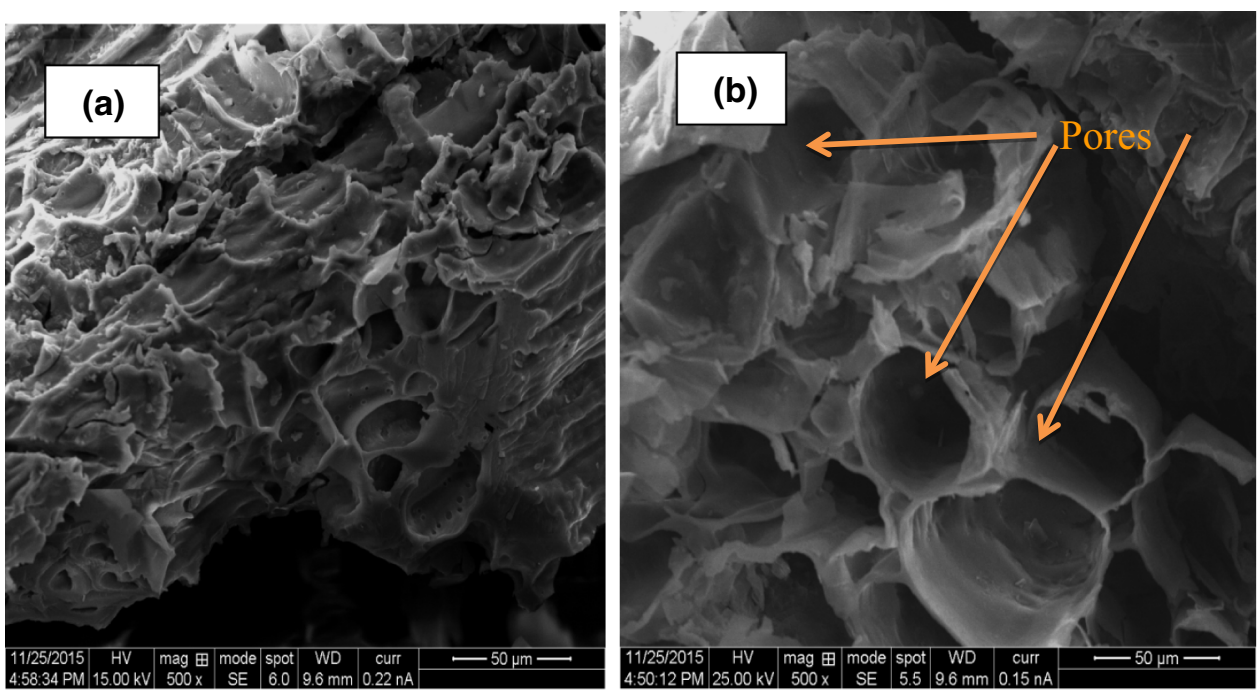
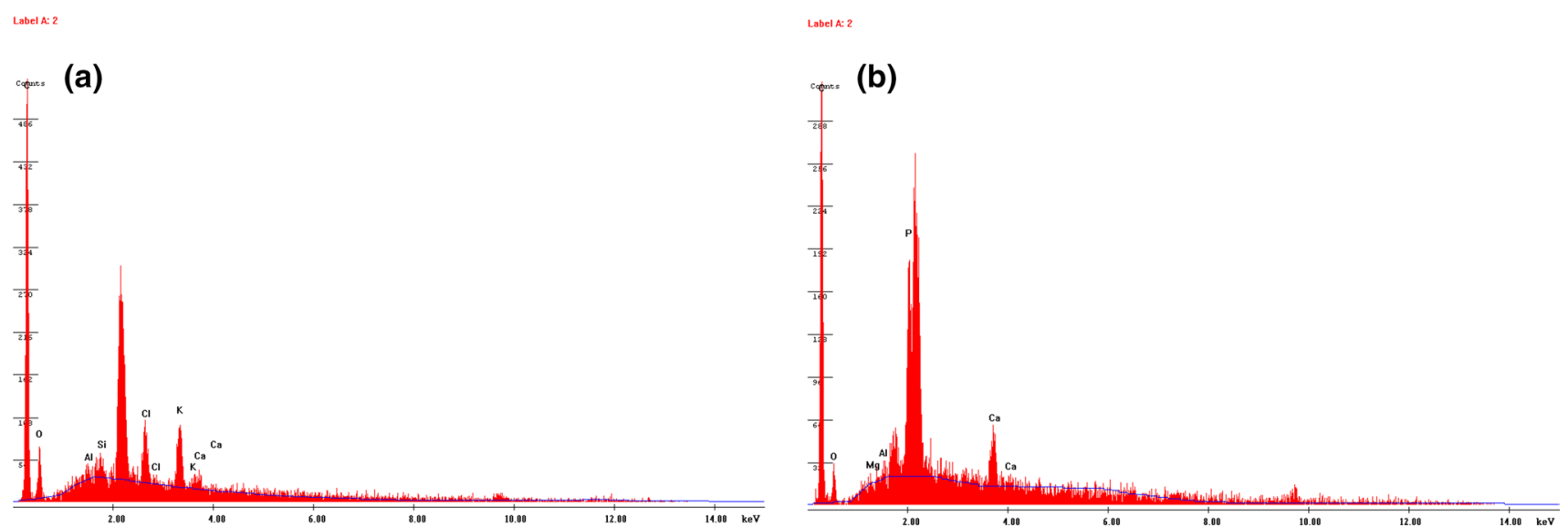

Fig. 3 EDX spectrum of $\mathbf{a}$ CHR and $\mathbf{b}$ CHA 
of pores coupled with an enhanced surface area is requisite properties of an effective adsorbent (Ahmad et al. 2016).

\section{Energy-dispersive X-ray}

Elemental analysis of both CHR and CHA was investigated by EDX to quantitatively determine the element(s) presents in both samples. Table 3 shows the differences between the amounts of carbon and oxygen in both samples. Similarly, Fig. 3a, b shows the EDX spectra of raw and activated samples, respectively. It was observed that $\mathrm{CHA}$ has a higher percentage by atom of carbon $(87.13 \%)$ and lower percentage by atom of oxygen $(4.99 \%)$ when compared with those obtained from CHR. This shows that the sample is predominantly carbonaceous in composition. We have previously reported that only the samples that are richer in carbon and lower in oxygen contents proved to be efficient adsorbents for removing dyes and other pollutants from the aqueous solutions (Bello et al. 2017a). This finding is consistent with other studies (Xiong et al. 2013; Kooh et al. 2016; Lim et al. 2017).

\section{Determination of oxygen-containing functional groups}

The Boehm titration technique was carried out to characterize the surface chemical properties of the acid activated adsorbent. Two assumptions were made before the

Table 3 Elemental analysis from EDX spectra of CHR and CHA

\begin{tabular}{llllll}
\hline Elements & \multicolumn{2}{l}{ CHR } & & \multicolumn{2}{l}{ CHA } \\
\cline { 2 - 3 } & wt $\%$ & at $\%$ & & wt $\%$ & at $\%$ \\
\hline $\mathrm{C}$ & 72.39 & 83.70 & & 75.46 & 87.13 \\
$\mathrm{O}$ & 11.82 & 10.26 & & 5.76 & 4.99 \\
$\mathrm{Mg}$ & Nil & Nil & & 0.17 & 0.10 \\
$\mathrm{Al}$ & 0.68 & 0.35 & & 0.42 & 0.21 \\
$\mathrm{Si}$ & 1.20 & 0.60 & & Nil & Nil \\
$\mathrm{Ca}$ & 1.52 & 0.53 & & 5.67 & 1.96 \\
$\mathrm{~K}$ & 7.82 & 2.78 & & Nil & Nil \\
$\mathrm{Cl}$ & 4.57 & 1.79 & & Nil & Nil \\
$\mathrm{P}$ & $\mathrm{Nil}$ & Nil & & 12.53 & 5.61 \\
Total & 100 & 100 & & 100 & 100 \\
\hline
\end{tabular}

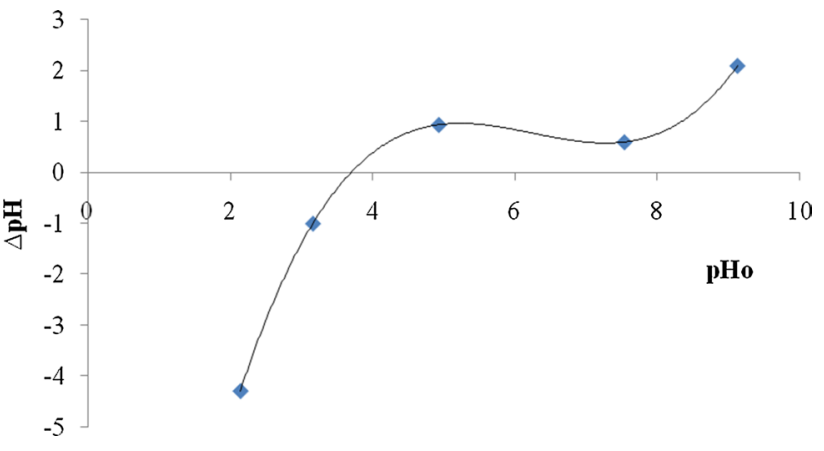

Fig. 4 Plot of $\mathrm{pH}_{\mathrm{pzc}}$ of activated coconut husk

surface acidity and basicity could be evaluated: (1) Acidic groups are neutralized by $\mathrm{NaHCO}_{3}, \mathrm{NaOH}$ or $\mathrm{Na}_{2} \mathrm{CO}_{3}$ and (2) $\mathrm{HCl}$ neutralized basic groups. Table 4 summarizes the properties of the surface functional groups obtained from the Boehm titration analysis using the previous procedures (Bello et al. 2017c, b). The concentration of acidic sites for AC produced from coconut husk (CHA) is $2.244 \mathrm{mmol} \mathrm{g}^{-1}$, while the basicity groups are very low given a corresponding value of $0.096 \mathrm{mmol} \mathrm{g}^{-1}$. It was observed that the adsorbent prepared has more acidic than basic functional groups after acid modification. This considerable increase in acidic groups in comparison with the basic groups suggests that the bulk of functional group(s) on the surface of the CHA is acidic. This is similar to result obtained in a study conducted on adsorption of barium and iron ions from the aqueous solution by AC obtained from mazot ash (Hilal et al. 2013).

\section{The $\mathrm{pH}$ point of zero charge $\left(\mathrm{pH}_{\mathrm{pzc}}\right)$ determination}

The $\mathrm{pH}_{\mathrm{pzc}}$ of activated carbon produced from coconut husk was calculated by determining the value at which the point of the resulting curve cuts through the $\mathrm{pH}_{\mathrm{o}}$ axis, i.e., [plotting the $\mathrm{pH}$ difference, $\Delta \mathrm{pH}$ (final $\mathrm{pH}$-initial $\mathrm{pH}$ ) against initial $\mathrm{pH}$ to determine the $\mathrm{pH}_{\mathrm{pzc}}$ ] (Dahri et al. 2016). As shown in Fig. 4, the $\mathrm{pH}_{\mathrm{pzc}}$ was determined to be at 3.69. This implies that adsorption of cations was improved at $\mathrm{pH}$ values higher than $\mathrm{pH}_{\mathrm{PZC}}$, while anions adsorption is favored at $\mathrm{pH}$ value less than $\mathrm{pH}_{\mathrm{PZC}}$ (Farahani et al. 2011; Bello et al. 2017b; Olakunle et al. 2018). It can be deduced from
Table 4 Boehm titration values of acid-activated coconut husk

\begin{tabular}{llllll}
\hline Adsorbent & \multicolumn{5}{l}{ Functional groups } \\
\cline { 2 - 6 } & $\begin{array}{l}\text { Carboxylic group } \\
\left(\mathrm{mmol} \mathrm{g}^{-1}\right)\end{array}$ & $\begin{array}{l}\text { Phenolic group } \\
\left(\mathrm{mmol} \mathrm{g}^{-1}\right)\end{array}$ & $\begin{array}{l}\text { Lactonic group } \\
\left(\mathrm{mmol} \mathrm{g}^{-1}\right)\end{array}$ & $\begin{array}{l}\text { Basic group } \\
\left(\mathrm{mmol} \mathrm{g}^{-1}\right)\end{array}$ & $\begin{array}{l}\text { Acidic } \\
\text { group } \\
\left(\mathrm{mmol} \mathrm{g}^{-1}\right)\end{array}$ \\
\hline CHA & 1.620 & 0.198 & 0.426 & 0.096 & 2.244 \\
\hline
\end{tabular}

The values reported are mean of triplicates. The standard error is \pm 0.001 
Fig. 4 that the combined influences of all the AC functional groups determine the $\mathrm{pH}_{\mathrm{pzc}}$, i.e., the $\mathrm{pH}$ at which the net surfaces charge on carbon was zero. At $\mathrm{pH}$ less than $\mathrm{pH}_{\mathrm{pzc}}$ $\left(\mathrm{pH}<\mathrm{pH}_{\mathrm{pzc}}\right)$, the carbon surface has a net positive charge whereas at $\mathrm{pH}$ greater than $\mathrm{pH}_{\mathrm{pzc}}\left(\right.$ at $\left.\mathrm{pH}>\mathrm{pH}_{\mathrm{pzc}}\right)$; the surface has a net negative charge (Al-Degs et al. 2000). This is consistent with Boehm titration results, indicating that acidic groups are dominant on the $\mathrm{CHA}$ surface. Since the $\mathrm{pH}_{\mathrm{PZC}}$ of CHA was 3.69 , it thus points out that the optimum amount of dye adsorbed will occur at $\mathrm{pH}>3.69$. Conversely, the experimental data disagreed with the concepts of $\mathrm{pH}_{\mathrm{PZC}}$, thereby suggesting an involvement of additional forces of attraction including the possibilities of dominance of hydrophobic-hydrophobic interactions than electrostatic interactions.

\section{Batch equilibrium studies}

\section{Effects of contact time and initial dye concentration}

Contact time and the initial dye concentrations have noticeable effects on the Rh-B dye adsorption onto CHA as shown in Fig. 5. The percentage of dye removed increases rapidly as contact time also increases; as the Rh-B dye molecules get locked-up in the free pores of the adsorbent, consequently, the trapping pores becomes limited. Thus, the amount of dye adsorbed decreased progressively and slowly until equilibrium is attained. There was relatively constant dye uptake at $25 \mathrm{~min}$ of the contact time, that is, 105-120 min. Our previous study has shown that the adsorption tends to be rapid in the first $10-15 \mathrm{~min}$ and steadily reduces until equilibrium is attained (Bello et al. 2017b). The reason for this was due to the large number of free pores on the surface of the activated coconut husk which enhanced the rapid uptake of $\mathrm{Rh}-\mathrm{B}$ dye at the initial stage. Eventually, at a prolonged contact time, most of the free pores are almost occupied with dye molecules, because there are few free pores compared to the untrapped Rh-B dye molecules; hence, the adsorption steadily reduces until equilibrium is attained. Adsorption is highly dependent on the initial dye concentration, because the percentage dye removal increases at lower initial dye concentrations and decreases at higher initial dye concentration; also the precise quantity of Rh-B dye adsorbed per unit mass of $\mathrm{CHA}$ increases with an increased in concentration of $\mathrm{Rh}-\mathrm{B}$ dye (Hema and Arivoli 2007).

\section{Adsorption isotherm studies}

At equilibrium, the experimental data obtained in this study were tested with four different isotherm models: Freundlich, Langmuir, DR and Temkin isotherms so as to determine the one that fitted most. The linear regression value $\left(R^{2}\right)$ and the maximum adsorption capacity $\left(q_{\mathrm{m}}\right)$ were used as the major operational parameters to justify the requisite of isotherm model fitness. $R^{2}$ values for the entire isotherm models were obtained from the plot a linear graph (Fig. 6), and their slopes and intercepts were used in calculating all other isotherm parameters. Linear plots were obtained at the temperatures studied. The results presented in Table 5 show that the adsorption data fitted most with the Langmuir isotherm model due to its highest value of $q_{\mathrm{m}}\left(\mathrm{mg} \mathrm{g}^{-1}\right)$ and $R^{2}$ closer to unity at all temperature studied (Table 5). In this study, we also showed isothermal nonlinear plots to avoid
Fig. 5 Effect of contact time and initial Rh-B dye concentration on $\mathrm{CHA}$ at $323 \mathrm{~K}$

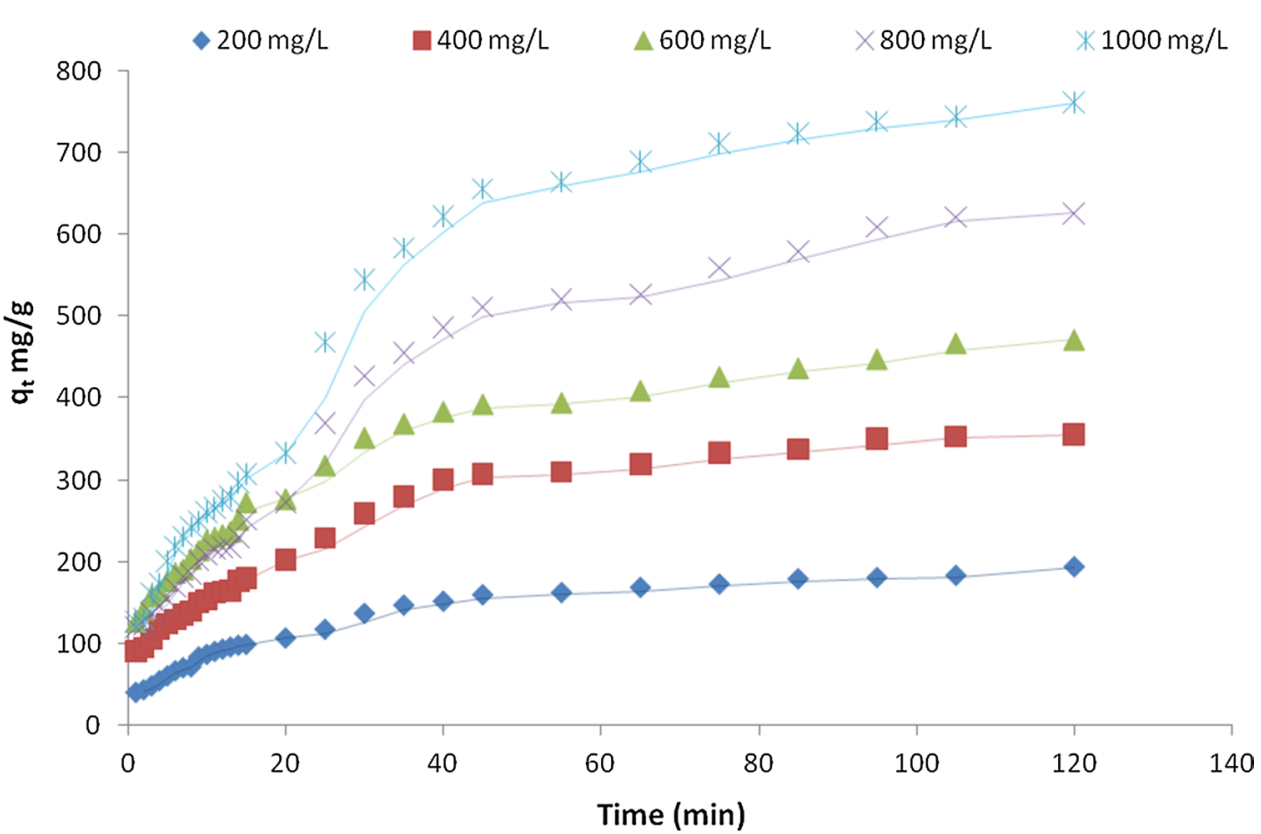

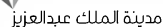

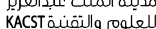


error(s) arising from different estimations that might result from linearized regression of isotherm equations shown in Table 2 which could significantly affect the values of $R^{2}$. Avoiding such error(s) became necessary so as to describe the adsorption isotherm for Rh-B dye uptake by CHA. Analysis via nonlinear method showed that saturation amounts of Langmuir are much closer to the experimental values with relatively low error functions than other isotherm models, thus confirming that Langmuir isotherm fitted most as presented in Fig. 7. This implies that the isotherm models used are valid and could effectively describe the equilibrium data. Figures 6 and 7 represent both linear and nonlinear models used in comparing experimental values of $\mathrm{Rh}-\mathrm{B}$ dye adsorption onto CHA.

\section{Effect of temperature on Rh-B-dye adsorption}

The amount of adsorbate adsorbed per unit mass of adsorbent $q_{\mathrm{e}},\left(\mathrm{mg} \mathrm{g}^{-1}\right)$ increases from 1111.11 to $1666.67 \mathrm{mg} \mathrm{g}^{-1}$ when temperature of the solution was increased from 303 to $323 \mathrm{~K}$, respectively. This increase indicates the nature of the process of adsorption. The result shows that increase in temperature favors the mobility of Rh-B dye molecules onto adsorbent (Fig. 8). The change in solution temperature increases the degree of randomness of the dye molecules and hence increases its mobility. The pores on the adsorbents were enhanced by the increased in temperatures which finally altogether facilitated a spontaneous adsorption process. Chemical interaction between $\mathrm{Rh}-\mathrm{B}$ and $\mathrm{CHA}$ was also
Table 5 Isotherm parameters for Rh-B dye adsorption onto $\mathrm{CHA}$ at different temperatures

\begin{tabular}{|c|c|c|c|}
\hline \multirow[t]{2}{*}{ Isotherms } & \multicolumn{3}{|c|}{ Temperature } \\
\hline & $303 \mathrm{~K}$ & $313 \mathrm{~K}$ & $323 \mathrm{~K}$ \\
\hline \multicolumn{4}{|l|}{ Langmuir } \\
\hline$q_{\mathrm{m}}\left(\mathrm{mg} \mathrm{g}^{-1}\right)$ & 1111.11 & 1250.00 & 1666.67 \\
\hline$K_{\mathrm{L}}\left(1 \mathrm{mg}^{-1}\right)$ & 0.0085 & 0.0116 & 0.0385 \\
\hline$R_{\mathrm{L}}$ & 0.105 & 0.079 & 0.025 \\
\hline$R^{2}$ & 0.9955 & 0.9967 & 0.9912 \\
\hline \multicolumn{4}{|l|}{ Freundlich } \\
\hline$\left.K_{\mathrm{f}}\left(\mathrm{mg} \mathrm{g}^{-1}\right)\left(\mathrm{mg}^{-1}\right)^{1 / n}\right)$ & 23.75 & 32.48 & 112.00 \\
\hline$N$ & 1.625 & 1.576 & 1.651 \\
\hline $1 / n$ & 0.6155 & 0.6347 & 0.6056 \\
\hline$R^{2}$ & 0.9849 & 0.9953 & 0.9983 \\
\hline \multicolumn{4}{|l|}{ Temkin } \\
\hline$B$ & 241.58 & 254.67 & 275.28 \\
\hline$b_{\mathrm{T}}\left(\mathrm{mol} \mathrm{kJ}^{-1}\right)$ & 0.103 & 0.101 & 0.096 \\
\hline$K_{\mathrm{T}}\left(\mathrm{mol} \mathrm{g}^{-1}\right)$ & 0.089 & 0.146 & 0.917 \\
\hline$R^{2}$ & 0.9995 & 0.9969 & 1 \\
\hline \multicolumn{4}{|l|}{ Dubinin-Radushkevich } \\
\hline$X_{\mathrm{m}}\left(\mathrm{mg} \mathrm{g}^{-1}\right)$ & 685.6 & 792.3 & 889.5 \\
\hline$\beta\left(10^{-4}\right)$ & 1.00 & 0.40 & 0.01 \\
\hline$E\left(\mathrm{~kJ} \mathrm{~mol}^{-1}\right)$ & 0.071 & 0.112 & 0.707 \\
\hline$R^{2}$ & 0.9861 & 0.9927 & 0.9789 \\
\hline
\end{tabular}

observed at higher temperature which resulted in the creation of higher affinities between the active sites and Rh-B
Fig. 6 Linear isotherm plots of: a Langmuir, b Freundlich, c Temkin, $\mathbf{d}$ DB-R for adsorption at $323 \mathrm{~K}$
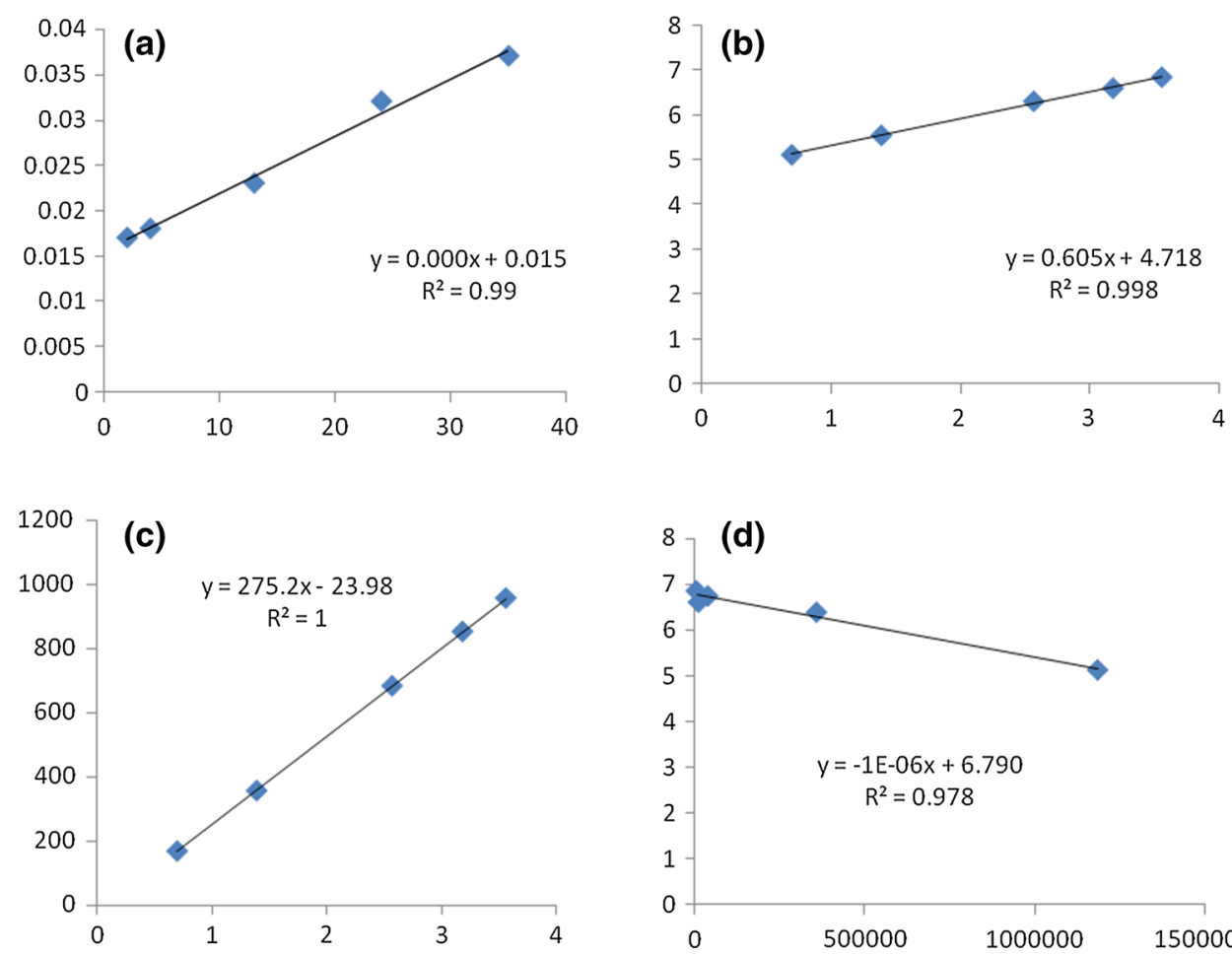

(d)

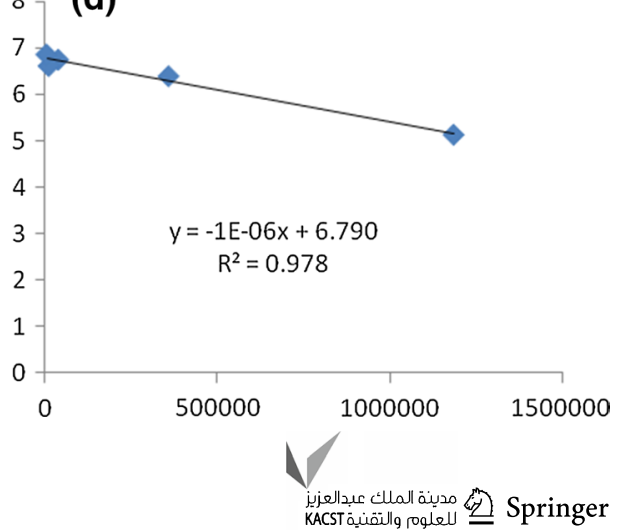




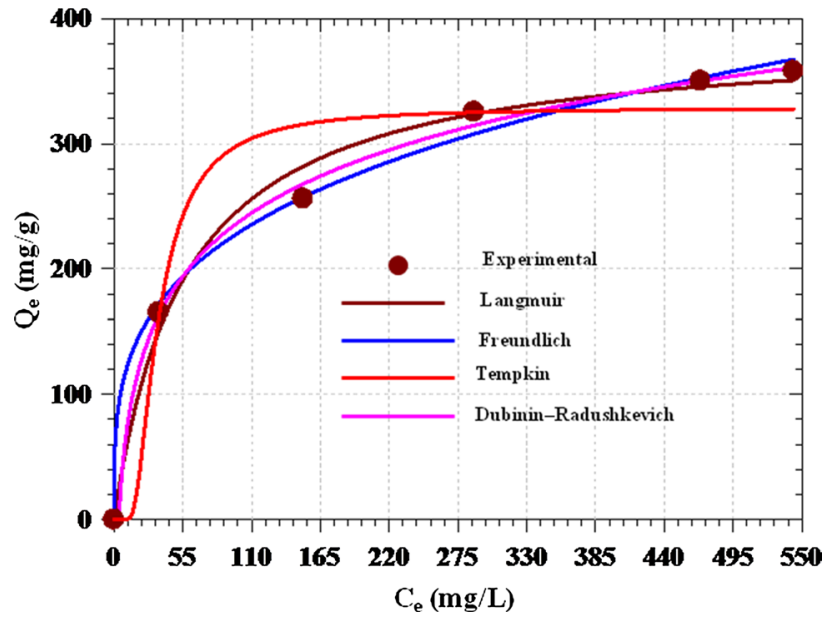

Fig. 7 Nonlinear isotherm plots of: a Langmuir, b Freundlich, c Temkin, $\mathbf{d} \mathrm{DB}-\mathrm{R}$ for adsorption at $323 \mathrm{~K}$

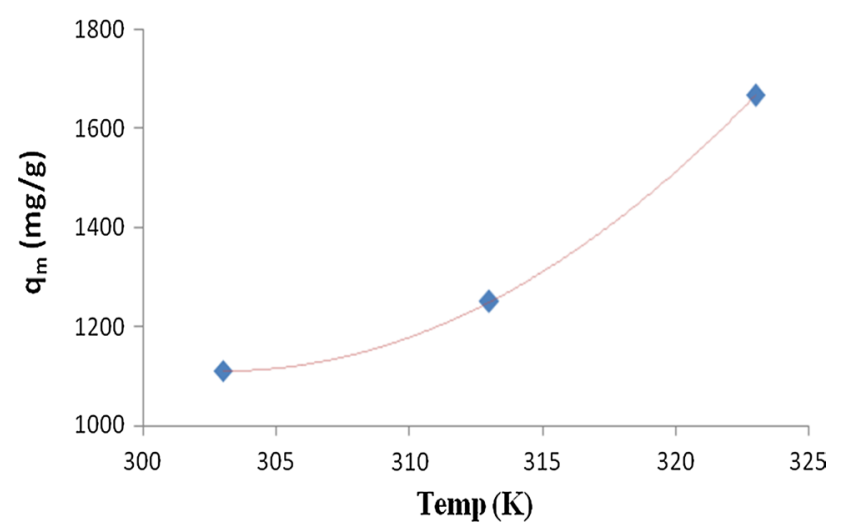

Fig. 8 Effect of temperature on the adsorption of Rh-B dye onto CHA

dye. More so, when temperature was changed, it altered the adsorbent equilibrium capacity (Hema and Arivoli 2007; Sureshkumar and Namasivayam 2008; Sadasivam et al. 2010; Gupta et al. 2012; Inyinbor et al. 2015; Dahri et al. 2016; Dharmendirakumar et al. 2016; Fu et al. 2016; Inyinbor et al. 2016; Kooh et al. 2016; Goswami and Phukan 2017; Iqbal et al. 2017; Adegoke et al. 2019). The capacity of adsorption for the most AC tends to increase with an increase in temperature, i.e., from 303 to $323 \mathrm{~K}$ (Hema and Arivoli 2007; Ahmad et al. 2016). Similar effects of temperature were observed from $\mathrm{Rh}-\mathrm{B}$ dye removal using Corchorus olitorius-L leaves (Subasri et al. 2015) and $R$. hookerie fruit epicarp (Inyinbor et al. 2016).

\section{Adsorption kinetic studies}

Four different kinetic models employed in this study to determine the processes of adsorption (PFO, PSO, Elovich and IPD models) are shown in Table 6. Figure 9 shows linearized plots of the four kinetic models for the Rh-B adsorption onto CHA. The linearized forms of Eqs. 14-14 were employed for fitting the equilibrium data. The values of $R^{2}$ obtained from isotherm models were correlated for the fitting the adsorption data. The closer the value of $R^{2}$ to unity, the better the fit. PSO kinetic model gave the best fit (Fig. 9) judging from $R^{2}$ value. $R^{2}$ obtained shows consistent trends, and thus, the rate constant was found to decrease consistently as the initial Rh-B dye concentration increases. This implies that equilibrium is reached at lower initial Rh-B dye concentration than at higher Rh-B dye concentration. The reason could be as a result of low competitions for CHA surface sites at low concentrations, whereas at high concentration, the competition for the CHA active surface sites increased (Ahmad et al. 2016). More so, high $R^{2}$ value close to unity suggests a better agreement between $q_{\mathrm{e}}$ and $q_{\text {cal }}$ values. We had previously obtained similar results in the adsorption of synthetic dye onto durian seeds (Ahmad et al. 2015).

The adsorption capacity of CHA was compared with other non-conventional adsorbents as listed in Table 7. $\mathrm{CHA}$ proved to be a better and sustainable adsorbent for the removing Rh-B dye among others. This is consistent with the findings reported in the literature on rhodamineB dyes (Namasivayam and Kanchana 1992; Wilhelm and Stephan 2007; Hema and Arivoli 2007; Sureshkumar and Namasivayam 2008; Vasu 2008; Parab et al. 2009; Li et al. 2010; Sadasivam et al. 2010; Gupta et al. 2012; Ashkarran et al. 2013; Gong et al. 2013; Inyinbor et al. 2015; Kooh et al. 2016; Dharmendirakumar et al. 2016; Dahri et al. 2016; Fu et al. 2016; Inyinbor et al. 2016; Iqbal et al. 2017; Singh et al. 2017; Suc and Kim Chi 2017; Cheng et al. 2017; Goswami and Phukan 2017; Adegoke et al. 2019).

\section{Adsorption thermodynamic studies}

Thermodynamic parameters such as $\Delta \mathrm{G}, \Delta \mathrm{H}$ and $\Delta \mathrm{S}$ are significant features in adsorption systems; these parameters are also key factors for adsorbent adsorption capacity (Tan et al. 2007). The values of $\Delta G, \Delta H$ and $\Delta S$ were calculated using Eqs. 15-17. The positive values of $\Delta S$ $\left(0.27625 \mathrm{~kJ} \mathrm{~mol}^{-1} \mathrm{~K}^{-1}\right)$ revealed the affinity of adsorbent for the Rh-B dye uptake and increasing randomness at the solid-solution interface during Rh-B dye adsorption onto the active sites of CHA (Hema and Arivoli 2007). The negative $\Delta G$ (ranging from -26.3762 to $-20.9291 \mathrm{~kJ} \mathrm{~mol}^{-1}$ ) obtained for the Rh-B dye adsorption onto CHA depicts the feasibility and spontaneity of the process of adsorption having higher preferences for the Rh-B dye onto $\mathrm{CHA}$, and 
Table 6 Kinetic parameters for Rh-B dye adsorption onto CHA at $323 \mathrm{~K}$

\begin{tabular}{lllllll}
\hline Models & Kinetic parameters & \multicolumn{4}{l}{ Initial Rh-B dye concentration $\left(\mathrm{mg} \mathrm{L}^{-1}\right)$} \\
\cline { 3 - 6 } & & 200 & 400 & 600 & 800 & 1000 \\
\hline Pseudo-first order & $q_{\mathrm{e}, \mathrm{cal}}\left(\mathrm{mg} \mathrm{g}^{-1}\right)$ & 262 & 428 & 509 & 724 & 914 \\
& $q_{\mathrm{e}, \mathrm{exp}}\left(\mathrm{mg} \mathrm{g}^{-1}\right)$ & 159 & 319 & 359 & 675 & 778 \\
& $k_{1}\left(\mathrm{~min}^{-1}\right)$ & 0.0562 & 0.0472 & 0.0389 & 0.0372 & 0.0338 \\
& $\mathrm{SSE}(\%)$ & 19.47 & 20.60 & 28.35 & 9.26 & 25.70 \\
& $R^{2}$ & 0.9667 & 0.9881 & 0.9795 & 0.9678 & 0.9921 \\
Pseudo-second order & $q_{\mathrm{e}, \mathrm{cal}}\left(\mathrm{mg} \mathrm{g}^{-1}\right)$ & 209 & 348 & 586 & 763 & 929 \\
& $q_{\mathrm{e}, \mathrm{exp}}\left(\mathrm{mg} \mathrm{g}^{-1}\right)$ & 214 & 335 & 579 & 779 & 918 \\
& $k_{2}\left(\mathrm{~min}^{-1}\right)$ & 0.00023 & 0.00017 & 0.00013 & 0.00003 & 0.00009 \\
& $\mathrm{SSE}(\%)$ & 0.95 & 2.46 & 1.32 & 3.02 & 2.08 \\
& $R^{2}$ & 0.9871 & 0.9885 & 0.9896 & 0.9911 & 0.9956 \\
& $\beta\left(\mathrm{g} \mathrm{mg}^{-1}\right)$ & 0.032 & 0.019 & 0.013 & 0.009 & 0.007 \\
& $\alpha\left[\mathrm{mg}^{-1}\left(\mathrm{~g}^{-1} \mathrm{~min}^{-1}\right)\right]$ & 199.09 & 307.06 & 527.17 & 547.76 & 599.89 \\
& $R^{2}$ & 0.9596 & 0.9337 & 0.9529 & 0.899 & 0.9097 \\
Elovich & $K_{t 1}\left(\mathrm{mg} \mathrm{g}^{-1} \mathrm{~h}^{1 / 2}\right)$ & 31.99 & 46.88 & 53.12 & 44.15 & 44.34 \\
& $C_{1}$ & 4.80 & 17.34 & 21.94 & 74.07 & 104.71 \\
& $R^{2}$ & 0.915 & 0.971 & 0.977 & 0.952 & 0.983 \\
& $K_{t 2}\left(\mathrm{mg} \mathrm{g}^{-1} \mathrm{~h}^{1 / 2}\right)$ & 8.511 & 14.188 & 20.025 & 21.797 & 44.34 \\
& $C_{2}$ & 79.681 & 123.12 & 126.38 & 104.71 & 133.93 \\
& $R^{2}$ & 0.954 & 0.964 & 0.958 & 0.973 & 0.983 \\
& $K_{t 3}\left(\mathrm{mg} \mathrm{g}^{-1} \mathrm{~h}^{1 / 2}\right)$ & 1.81 & 2.03 & 2.24 & 3.08 & 3.28 \\
& $C_{3}$ & 125.23 & 213.43 & 196.43 & 217.50 & 239.16 \\
& $R^{2}$ & 0.957 & 0.957 & 0.957 & 0.957 & 0.957 \\
\hline & & & & & &
\end{tabular}

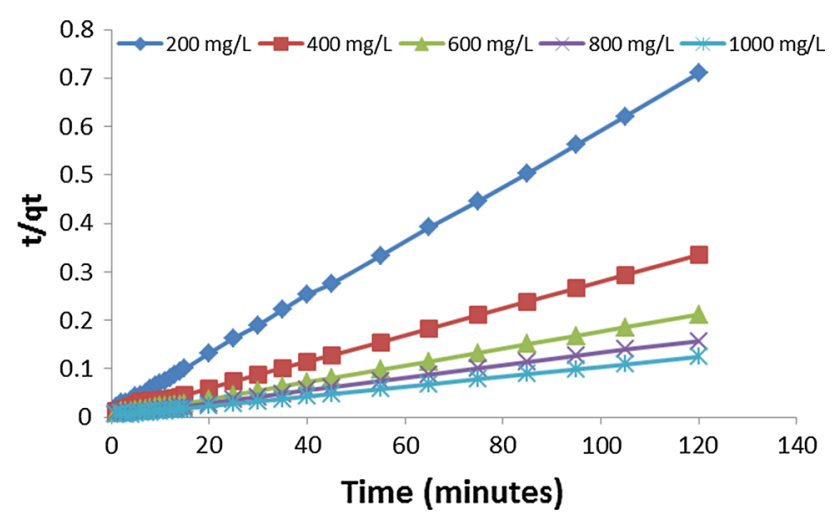

Fig. 9 Plot of pseudo-second-order kinetic model at $323 \mathrm{~K}$ for Rh-B dye adsorption onto CHA

also the $\Delta \mathrm{H}$ positive value $\left(62.7707 \mathrm{~kJ} \mathrm{~mol}^{-1}\right)$ revealed the endothermic nature of the adsorption process (Table 8).

\section{Mechanism of adsorption}

Although several factors control the adsorption rate $(\mathrm{Wu}$ et al. 2001; Gerçel et al. 2008; Bello et al. 2017b; Ojedokun and Bello 2017), the mechanism of adsorption is the most significant factor governing the kinetics of adsorption in which there is occurrence of initial curved portion
Table 7 Comparison of adsorption capacities of Rh-B dye with various adsorbents

\begin{tabular}{|c|c|c|}
\hline Adsorbents & $q_{\mathrm{m}}\left(\mathrm{mg} \mathrm{g}^{-1}\right)$ & References \\
\hline Sugarcane baggase & 65.5 & Zhang et al. (2013) \\
\hline $\begin{array}{l}\text { Acid treated montmoril- } \\
\text { lonite }\end{array}$ & 188.67 & Bhattacharyya et al. (201 \\
\hline Fuller's Earth & 193.11 & Subbareddy et al. (2014) \\
\hline Corchorus olitorius leave & 572.69 & Subasri et al. (2015) \\
\hline Prosopisjuli flora bark & 612.66 & Arivoli et al. (2014) \\
\hline Cyamopsistetra gonoloba & 563.10 & Arivoli et al. (2016) \\
\hline $\begin{array}{l}\text { Raphia hookerie fruit } \\
\text { epicarp }\end{array}$ & 666.67 & Inyinbor et al. (2016) \\
\hline Moringa oleifera seed pod & 1250 & Bello et al. (2017a, b, c) \\
\hline Activated coconut husk & 1666.67 & This study \\
\hline
\end{tabular}

owing to a very fast surface adsorption and external diffusion of Rh-B dye onto CHA (Bello et al. 2017b). This present study shows multilinear plots which agreed with our previous study (Bello et al. 2017b). From Fig. 10, the $K_{t 1}$ part is the sharper region called the boundary diffusion layer of Rh-B dye molecules while the $K_{t 2}$ part is attributed to a slower and moderate phase revealing the intraparticle diffusion (IPD) as the slowest step called the rate-determining step (RDS). The masses transfers 
Table 8 Thermodynamic parameters for adsorption onto CHA

\begin{tabular}{|c|c|c|c|c|c|}
\hline \multirow[t]{2}{*}{ Adsorbent } & \multirow[t]{2}{*}{$\Delta S^{\mathrm{o}}\left(\mathrm{kJ} \mathrm{mol}^{-1} \mathrm{~K}\right)$} & \multirow[t]{2}{*}{$\Delta H^{\mathrm{o}}\left(\mathrm{kJ} \mathrm{mol}^{-1}\right)$} & \multicolumn{3}{|c|}{$\Delta G^{\mathrm{o}}\left(\mathrm{kJ} \mathrm{mol}^{-1}\right)$} \\
\hline & & & $303 \mathrm{~K}$ & $313 \mathrm{~K}$ & $323 \mathrm{~K}$ \\
\hline CHA & 62.7707 & 0.27625 & -20.9291 & -22.4280 & -26.3762 \\
\hline
\end{tabular}

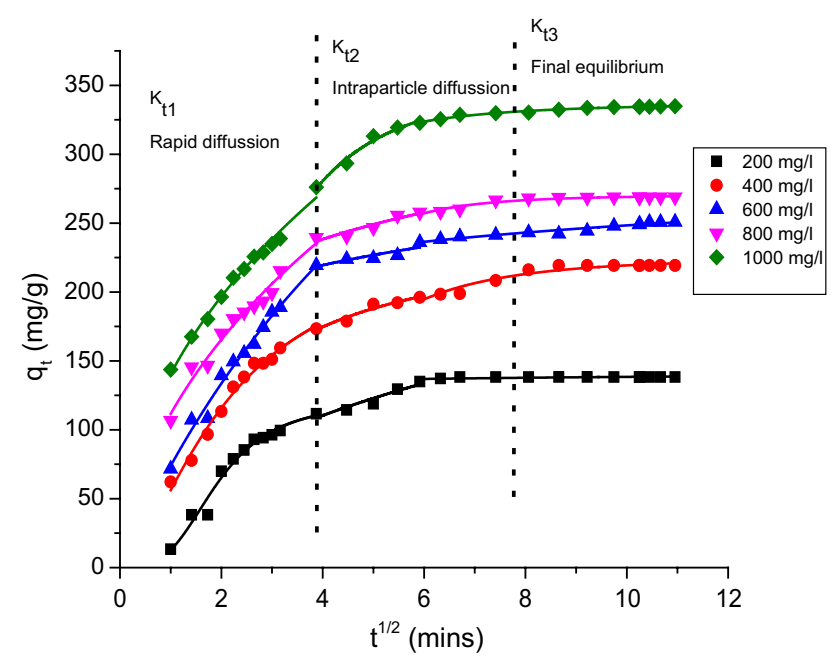

Fig. 10 Plot of intraparticle diffusion model for Rh-B dye adsorption onto CHA

are controlled by various relationships: mechanism of adsorption, liquid-solid phase coupling and initial-toboundary factors. It therefore connotes that equilibrium rate attainments was IPD-controlled (Bello et al. 2017b). Subsequent to the initial faster adsorption phase, there existed a stage where adsorption of Rh-B was relatively gradual with IPD being the rate controlled. Following this was the relatively slower adsorption process with a linear stability to approach plateau (equilibrium) called the maximum sorption stage. The IPD model constant values $k_{t}$ and $C$ are determined from the $q_{\mathrm{t}}\left(\mathrm{mg} \mathrm{g}^{-1}\right)$ versus $t^{1 / 2}$ $\left(h^{1 / 2}\right)$ plot as shown in Table 6 . The nonlinearity of the $q_{t}\left(\mathrm{mg} \mathrm{g}^{-1}\right)$ versus $t^{1 / 2}\left(h^{1 / 2}\right)$ plot obtained for Rh-B dye adsorption onto CHA (Fig. 10) with deviation from zero revealed that IPD was not the only rate-determining step. However, it was observed that $K_{t 2}$ part characterized by the IPD was established to be the rate-determining step. The plots with nonzero origin $(C \neq 0)$ showed an occurrence of IPD in the adsorption process but not the only controlling parameter for the reaction rate. The intercept " $C$ " shows a proportionality relationship with boundary layers having the observable extent of thickness at $323 \mathrm{~K}$ (Bello et al. 2017b). More so, there is increased in the boundary layer effects with " $C$ " values. This actually helped in knowing the adsorbent tendency to either adsorb Rh-B dyes
Table 9 Price difference between CHA and CAC

\begin{tabular}{lll}
\hline Cost description & \multicolumn{2}{l}{ Price (US \$) } \\
\cline { 2 - 3 } & CHA $(1 \mathrm{~kg})$ & CAC $(1 \mathrm{~kg})$ \\
\hline Transportation & 8.33 & 4.5 \\
$o$-Phosphoric acid & 20.84 & - \\
Deionized water & 8.65 & - \\
Filter paper & 3.00 & - \\
Electricity & 2.14 & - \\
Cost of purchase & - & 255 \\
Total & 42.96 & 259.5 \\
Difference (CAC-CHA) & 216.54 & \\
\hline
\end{tabular}

or remain in the solutions. The obtained high " $C$ " values depict an enhanced adsorption capacity. This observation agreed well with the existing literature (Tan et al. 2008; Bello et al. 2017b; Ojedokun and Bello 2017; Khasri et al. 2018).

\section{Cost analysis}

The cost analysis presented in Table 9 provides a simple proof that CHA is six times cheaper than CAC. CAC costs 259.5 US\$ per $\mathrm{kg}$ (transportation inclusive) in total, while CHA preparation and transportation cost 42.96 US $\$$ per $\mathrm{kg}$. The low cost of preparing CHA as stated in Table 9 gave detailed summary of prices from coconut husk transportation to filtration and washing of the AC. Orthophosphoric acid and deionized water account for most of the significant cost (Table 9).

\section{Conclusion}

CHA, an economically viable material prepared from agricultural waste, is a good precursor for adsorbing rhodamineB dye from its solutions. The adsorption data fitted most to Langmuir isotherm among all the models used with a maximum monolayer adsorption capacity of $1666.67 \mathrm{mg} \mathrm{g}^{-1}$ and a highest regression value of 0.99 which implies that CHA has greater affinity for the adsorption of Rh-B dyes owing to its pore development via acid activation resulting in higher adsorption capacity. The adsorption process was best explained by PSO kinetic model. The process of adsorption was described to be both endothermic and spontaneous. The positive value of $\Delta S^{0}\left(0.276 \mathrm{~kJ} \mathrm{~mol}^{-1} \mathrm{~K}^{-1}\right)$ suggests 
increased randomness between adsorbent-adsorbate interactions. The adsorption of Rh-B dye onto CHA was highly dependent on operational parameters (contact time, initial dye concentrations and solution $\mathrm{pH}$ ). This study revealed that CHA prepared form coconut husk waste material is a promising and sustainable sorbent for removing $\mathrm{Rh}-\mathrm{B}$ dye from aqueous solution owing to its sustained availability.

Acknowledgements The first and corresponding authors acknowledge the supports got from the World Academy of Science (TWAS) in form of Research grants; Research Grant Number: 11-249 RG/CHE/ AF/AC_1_UNESCO FR: 3240262674 (2012), 15-181 RG/CHE/AF/ AC_1_: 3240287083 (2015) for the purchase of Research Equipments. NRF-TWAS for Doctoral Fellowship award given to the second author (UID:105453 and Reference: SFH160618172220) and LAUTECH 2016 TET Fund Institution Based Research Intervention (TETFUND/ DESS/UNI/OGBOMOSO/RP/VOL. IX), respectively.

\section{Compliance with ethical standards}

Conflict of interest The authors declare no conflict of interest.

Open Access This article is distributed under the terms of the Creative Commons Attribution 4.0 International License (http://creativeco mmons.org/licenses/by/4.0/), which permits unrestricted use, distribution, and reproduction in any medium, provided you give appropriate credit to the original author(s) and the source, provide a link to the Creative Commons license, and indicate if changes were made.

\section{References}

Adegoke KA, Bello OS (2015) Dye sequestration using agricultural wastes as adsorbents. Water Resour Ind 12:8-24. https://doi. org/10.1016/j.wri.2015.09.002

Aharoni C, Ungarish M (1976) Kinetics of activated chemisorptions. Part I: the non-Elovichian part of the isotherm. J Chem Soc Farad Trans 72:265-268

Adegoke KA, Oyewole RO, Lasisi BM, Bello OS (2017) Abatement of organic pollutants using fly ash based adsorbents. Water Sci Technol 76:2580-2592. https://doi.org/10.2166/wst.2017.437

Adegoke KA, Iqbal M, Louis H, Bello OS (2019) Synthesis, characterization and application of $\mathrm{CdS} / \mathrm{ZnO}$ nanorod heterostructure for the photodegradation of Rhodamine B dye. Mater Sci Energy Technol 2:329-336. https://doi.org/10.1016/J.MSET.2019.02.008

Adeyemo AA, Adeoye IO, Bello OS (2017) Adsorption of dyes using different types of clay: a review. Appl Water Sci 7:543-568. https ://doi.org/10.1007/s13201-015-0322-y

Ahmad MA, Ahmad N, Bello OS (2015) Modified durian seed as adsorbent for the removal of methyl red dye from aqueous solutions. Appl Water Sci 5:407-423. https://doi.org/10.1007/s1320 1-014-0208-4

Ahmad MA, Afandi NS, Adegoke KA, Bello OS (2016) Optimization and batch studies on adsorption of malachite green dye using rambutan seed activated carbon. Desalin Water Treat 57:2148721511. https://doi.org/10.1080/19443994.2015.1119744

Al-Degs YS, Tutunju MF, Shawabkeh RA (2000) The feasibility of using diatomite and $\mathrm{Mn}$-diatomite for remediation of $\mathrm{Pb}^{2+}, \mathrm{Cu}^{2+}$, and $\mathrm{Cd}^{2+}$ from water. Sep Sci Technol. https://doi.org/10.1081/ SS-100102103

AlOthman ZA, Habila MA, Ali R et al (2014) Valorization of two waste streams into activated carbon and studying its adsorption kinetics, equilibrium isotherms and thermodynamics for methylene blue removal. Arab J Chem. https://doi.org/10.1016/j.arabj c.2013.05.007

Ajemba RO (2014) Adsorption of Malachite green from aqueous solution using activated Ntezi clay: optimization. Isotherm and Kinetic Studies. Int J Eng 27:839-854

Arivoli S, Thilagavathi M, Vijayakumaran V (2014) Kinetic and thermodynamic studies on the adsorption behavior of Rhodamine B dye using Prosopis Juliflora Bark carbon. Scholars J Eng Technol 2(2B):258-263

Arivoli S, Yamunadevi R, Venkat CH, Aalam R, Marimuthu V (2016) Kinetic, thermodynamic and isotherm studies on the removal of Rhodamine B dye using activated Cyamopsistetragonoloba stem nano carbon. J Chem Biol Phys Sci Sect A 6(3):932-943

Ashkarran AA, Mahmoudi E, Saviz S (2013) $\mathrm{TiO}_{2}$ nanofibre-assisted photodecomposition of Rhodamine $\mathrm{B}$ from aqueous solution. J Exp Nanosci 8:678-687. https://doi.org/10.1080/17458 080.2011.616538

Bello OS, Siang TT, Ahmad MA (2012) Adsorption of Remazol Brilliant Violet-5R reactive dye from aqueous solution by cocoa pod husk-based activated carbon: kinetic, equilibrium and thermodynamic studies. Asia Pac J Chem Eng 7:378-388. https://doi. org/10.1002/apj.557

Bello OS, Adegoke KA, Olaniyan AA, Abdulazeez H (2015) Dye adsorption using biomass wastes and natural adsorbents: overview and future prospects. Desalin Water Treat 53:1292-1315. https://doi.org/10.1080/19443994.2013.862028

Bello OS, Adegoke KA, Akinyunni OO (2017a) Preparation and characterization of a novel adsorbent from Moringa oleifera leaf. Appl Water Sci 7:1295-1305. https://doi.org/10.1007/ s13201-015-0345-4

Bello OS, Lasisi BM, Adigun OJ, Ephraim V (2017b) Scavenging Rhodamine B dye using Moringa oleifera seed pod. Chem Speciat Bioavailab 29:120-134. https://doi.org/10.1080/09542 299.2017.1356694

Bello OS, Owojuyigbe ES, Babatunde MA, Folaranmi FE (2017c) Sustainable conversion of agro-wastes into useful adsorbents. Appl Water Sci 7:3561-3571. https://doi.org/10.1007/s1320 1-016-0494-0

Bhattacharyya KG, SenGutpa S, Sarma GK (2014) Interactions of the dye, rhodamine B with kaolinite and montmorillonite in water. Appl Clay Sci 99:7-17

Boehm HP (2002) Surface oxides on carbon and their analysis: a critical assessment. Carbon. https://doi.org/10.1016/S0008 $-6223(01) 00165-8$

Cheng ZL, Li Y-x, Liu Z (2017) Fabrication of graphene oxide/ silicalite-1 composites with hierarchical porous structure and investigation on their adsorption performance for rhodamine B. J Ind Eng Chem 55:234-243. https://doi.org/10.1016/j. jiec.2017.06.054

Dahri MK, Kooh MRR, Lim LBL (2016) Remediation of rhodamine B dye from aqueous solution using Casuarina equisetifolia cone powder as a low-cost adsorbent. Adv Phys Chem 2016:1-14. https ://doi.org/10.1155/2016/9497378

Deschaux O, Spennato G, Moreau JL, Garcia R (2011) Chronic treatment with fluoxetine prevents the return of extinguished auditorycued conditioned fear. Psychopharmacology 215:231-237. https ://doi.org/10.1007/s00213-010-2134-y

Dharmendirakumar M, Vijayakumar G, Tamilarasan R et al (2016) Adsorption of Rhodamine-B and Congo red dye from aqueous solution using activated carbon: kinetics, isotherms, and thermodynamics. J Hazard Mater 6:157-170. https://doi.org/10.1016/j. jhazmat.2007.11.025

Dubinin MM (1960) The potential theory of adsorption of gases and vapors for adsorbents with energetically non-uniform surface. Chem Rev 60:235-266

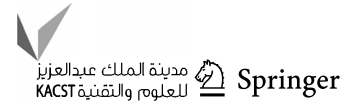


Ekpete OA, Horsfall MJNR (2011) Preparation and characterization of activated carbon derived from fluted pumpkin stem waste ( $\mathrm{Tel}$ fairia occidentalis Hook F). Res J Chem Sci 1:10-17. https://doi. org/10.1688/1862-0000_ZfP_2009_02_Hormuth

Farahani M, Abdullah SRS, Hosseini S et al (2011) Adsorption-based cationic dyes using the carbon active sugarcane bagasse. Procedia Environ Sci. https://doi.org/10.1016/j.proenv.2011.09.035

Freundlich HM (1906) Over the adsorption in solution. J Phys Chem $57: 385-470$

Fu J, Xin Q, Wu X et al (2016) Selective adsorption and separation of organic dyes from aqueous solution on polydopamine microspheres. J Colloid Interface Sci. https://doi.org/10.1016/j. jcis.2015.09.017

Gerçel Ö, Gerçel HF, Koparal AS, Öğütveren ÜB (2008) Removal of disperse dye from aqueous solution by novel adsorbent prepared from biomass plant material. J Hazard Mater 160:668-674. https ://doi.org/10.1016/j.jhazmat.2008.03.039

Gong L, Sun W, Kong L (2013) Adsorption of methylene blue by $\mathrm{NaOH}-$ modified dead leaves of plane trees. Comput Water Energy Environ Eng. https://doi.org/10.4236/cweee.2013.22B003

Goswami M, Phukan P (2017) Enhanced adsorption of cationic dyes using sulfonic acid modified activated carbon. J Environ Chem Eng 5:3508-3517. https://doi.org/10.1016/j.jece.2017.07.016

Goyal M, Singh S, Bansal RC (2004) Equilibrium and dynamic adsorption of methylene blue from aqueous solutions by surface modified activated carbons.Carbon Lett 5(4):170-179

Gupta VK, Jain R, Shrivastava M (2010) Adsorptive removal of Cyanosine from wastewater using coconut husks. J Colloid Interface Sci 347:309-314. https://doi.org/10.1016/j.jcis.2010.03.060

Gupta N, Kushwaha AK, Chattopadhyaya MC (2012) Adsorption studies of cationic dyes onto Ashoka (Saraca asoca) leaf powder. J Taiwan Inst Chem Eng 43:604-613. https://doi.org/10.1016/j.jtice .2012 .01 .008

Hameed BH, Din ATM, Ahmad AL (2007) Adsorption of methylene blue onto bamboo-based activated carbon: kinetics and equilibrium studies. J Hazard Mater 141:819-825. https://doi. org/10.1016/j.jhazmat.2006.07.049

Hayeeye F, Sattar M, Tekasakul S, Sirichote O (2014) Adsorption of Rhodamine B on activated carbon obtained from pericarp of rubber fruit in comparison with the commercial activated carbon. Songklanakarin J Sci Technol 36:177-187

Hema M, Arivoli S (2007) Comparative study on the adsorption kinetics and thermodynamics of dyes onto acid activated low cost carbon. Int J Phys Sci 2:10-17

Ho YS, McKay G (1999) Pseudo-second order model for sorption processes. Proc Biochem 34:451-465

Hilal NM, Emam AA, Badawy NA, Zidan AE (2013) Adsorption of barium and iron ions from aqueous solutions by the activated carbon produced from mazot ash. Life Sci J 10:75-83

Inyinbor AA, Adekola FA, Olatunji GA (2015) Adsorption of Rhodamine B dye from aqueous solution on Irvingia gabonensis biomass: kinetics and thermodynamics studies. S Afr J Chem 68:115-125. https://doi.org/10.17159/0379-4350/2015/v68a17

Inyinbor AA, Adekola FA, Olatunji GA (2016) Kinetics, isotherms and thermodynamic modeling of liquid phase adsorption of Rhodamine B dye onto Raphia hookerie fruit epicarp. Water Resour Ind. https://doi.org/10.1016/j.wri.2016.06.001

Iqbal M, Thebo AA, Shah AH et al (2017) Influence of Mn-doping on the photocatalytic and solar cell efficiency of $\mathrm{CuO}$ nanowires. Inorg Chem Commun 76:71-76. https://doi.org/10.1016/j.inoch e.2016.11.023

Jain A, Balasubramanian R, Srinivasan MP (2015) Production of high surface area mesoporous activated carbons from waste biomass using hydrogen peroxide-mediated hydrothermal treatment for adsorption applications. Chem Eng J. https://doi.org/10.1016/j. cej.2015.03.111

Jawad AH, Rashid RA, Ishak MAM, Wilson LD (2016) Adsorption of methylene blue onto activated carbon developed from biomass waste by $\mathrm{H} 2 \mathrm{SO} 4$ activation: kinetic, equilibrium and thermodynamic studies. Desalin Water Treat 57:25194-25206. https://doi. org/10.1080/19443994.2016.1144534

Khan MMR, Ray M, Guha AK (2011) Mechanistic studies on the binding of Acid Yellow 99 on coir pith. Bioresour Technol. https://doi. org/10.1016/j.biortech.2010.10.107

Khasri A, Bello OS, Ahmad MA (2018) Mesoporous activated carbon from Pentace species sawdust via microwave-induced $\mathrm{KOH}$ activation: optimization and methylene blue adsorption. Res Chem Intermed 44:5737-5757. https://doi.org/10.1007/s1116 4-018-3452-7

Kooh MRR, Dahri MK, Lim LBL (2016) The removal of rhodamine $\mathrm{B}$ dye from aqueous solution using Casuarina equisetifolia needles as adsorbent. Cogent Environ Sci 2:1-14. https://doi. org/10.1080/23311843.2016.1140553

Lagergren S (1898) Zur Theorie der sogenannten Adsorption Geloester Stoffe. Veternskapsakad Handl 24:1-39

Langmuir I (1918) The adsorption of gases on plane surfaces of glass, mica and platinum. J Am Chem Soc 40:1361-1403

Li L, Liu S, Zhu T (2010) Application of activated carbon derived from scrap tires for adsorption of Rhodamine B. J Environ Sci 22:1273-1280. https://doi.org/10.1016/S1001-0742(09)60250-3

Lim LBL, Priyantha N, Fang XY, Mohamad Zaidi NAH (2017) Artocarpusodoratissimus peel as a potential adsorbent in environmental remediation to remove toxic Rhodamine B dye. J Materials Environ Sci J Mater Environ Sci 8:494-502

Mittal A, Mittal J, Malviya A et al (2010) Decoloration treatment of a hazardous triarylmethane dye, Light Green SF (Yellowish) by waste material adsorbents. J Colloid Interface Sci 342:518-527. https://doi.org/10.1016/j.jcis.2009.10.046

Namasivayam C, Kanchana N (1992) Waste banana pith as adsorbent for color removal from wastewaters. Chemosphere 25:1691-1705. https://doi.org/10.1016/0045-6535(92)90316-J

Namasivayam C, Sangeetha D (2006) Recycling of agricultural solid waste, coir pith: removal of anions, heavy metals, organics and dyes from water by adsorption onto $\mathrm{ZnCl}_{2}$ activated coir pith carbon. J Hazard Mater 135:449-452. https://doi.org/10.1016/j.jhazm at.2005.11.066

Namasivayam C, Sangeetha D, Gunasekaran R (2007) Removal of anions, heavy metals, organics and dyes from water by adsorption onto a new activated carbon from Jatropha husk, an agroindustrial solid waste. Process Saf Environ Prot 85:181-184. https ://doi.org/10.1205/psep05002

Ojedokun AT, Bello OS (2017) Kinetic modeling of liquid-phase adsorption of Congo red dye using guava leaf-based activated carbon. Appl Water Sci 7:1965-1977. https://doi.org/10.1007/ s13201-015-0375-y

Ojo TA, Ojedokun AT, Bello OS (2019) Functionalization of powdered walnut shell with orthophosphoric acid for Congo red dye removal. Part Sci Technol 37:74-85

Olakunle MO, Inyinbor AA, Dada AO, Bello OS (2018) Combating dye pollution using cocoa pod husks: a sustainable approach. Int J Sustain Eng 11:4-15. https://doi.org/10.1080/19397 038.2017.1393023

Parab H, Sudersanan M, Shenoy N et al (2009) Use of agro-industrial wastes for removal of basic dyes from aqueous solutions. Clean Soil Air Water 37:963-969. https://doi.org/10.1002/clen.20090 0158

Patel H (2018) Charcoal as an adsorbent for textile wastewater treatment. Sep Sci Technol (Philadelphia) 53:2797-2812. https://doi. org/10.1080/01496395.2018.1473880 
Rani KC, Naik A, Chaurasiya RS, Raghavarao KSMS (2017) Removal of toxic Congo red dye from water employing low-cost coconut residual fiber. Water Sci Technol 75:2225-2236. https://doi. org/10.2166/wst.2017.109

Rashid RA, Jawad AH, Ishak MABM, Kasim NN (2018) FeCl 3 -activated carbon developed from coconut leaves: characterization and application for methylene blue removal. Sains Malays 47:603610. https://doi.org/10.17576/jsm-2018-4703-22

Saad SA, Isa KM, Bahari R (2010) Chemically modified sugarcane bagasse as a potentially low-cost biosorbent for dye removal. Desalination 264:123-128. https://doi.org/10.1016/j.desal .2010.07.015

Sadasivam S, Krishna SK, Ponnusamy K et al (2010) Equilibrium and thermodynamic studies on the adsorption of an organophosphorous pesticide onto "waste" jute fiber carbon. J Chem Eng Data 55:5658-5662. https://doi.org/10.1021/je1005906

Singh M, Kumar P, Mamta Bhagat DPT (2017) Removal of rhodamine $\mathrm{B}$ from aqueous solution by $\mathrm{ZnO}$ nanoparticles. Int $\mathrm{J}$ Innov Res Sci Eng Technol 6:4050-4056. https://doi.org/10.15680/IJIRS ET.2017.0603176

Somasekhara Reddy MC, Nirmala V, Ashwini C (2017) Bengal Gram Seed Husk as an adsorbent for the removal of dye from aqueous solutions—batch studies. Arab J Chem. https://doi.org/10.1016/j. arabjc.2013.09.029

Subasri S, Arivoli S, Marimuthu V, Mani N (2015) From aqueous solution using activated Corchorus olitorius-L leaves. Int J Plant Anim Environ Serv 5(1):208-218

Subbareddy Y, Jayakumar C, Valliammai S, Nagaraja KS, Jeyaraj B (2014) Equilibrium, kinetic and thermodynamic study of adsorption of Rhodamine B dye from aqueous solution by fuller's earth. Int J Res Chem Environ 4(3):16-25

Suc NV, Kim Chi D (2017) Removal of rhodamine B from aqueous solution via adsorption onto microwave-activated rice husk ash. J Dispers Sci Technol 38:216-222. https://doi.org/10.1080/01932 691.2016.1155153

Sureshkumar MV, Namasivayam C (2008) Adsorption behavior of Direct Red 12B and Rhodamine B from water onto surfactantmodified coconut coir pith. Colloids Surf A Physicochem Eng Aspects. https://doi.org/10.1016/j.colsurfa.2007.10.026

Sydorchuk V, Poddubnaya OI, Tsyba MM et al (2019) Activated carbons with adsorbed cations as photocatalysts for pollutants degradation in aqueous medium. Adsorption 25:267-278. https://doi. org/10.1007/s 10450-018-00006-0

Tan IAW, Hameed BH, Ahmad AL (2007) Equilibrium and kinetic studies on basic dye adsorption by oil palm fibre activated carbon. Chem Eng J 127:111-119. https://doi.org/10.1016/j. cej.2006.09.010

Tan IAW, Ahmad AL, Hameed BH (2008) Enhancement of basic dye adsorption uptake from aqueous solutions using chemically modified oil palm shell activated carbon. Colloids Surf A 318:88-96. https://doi.org/10.1016/j.colsurfa.2007.12.018

Temkin M, Pyzhev V (1940) Kinetics of ammonia synthesis on promoted iron catalysts. Acta physiochim URSS 12(3):217-222

Thirumalisamy S, Subbian M (2010) Removal of methylene blue from aqueous solution by activated carbon prepared from the peel of cucumis sativa fruit by adsorption. BioResources. https://doi. org/10.3329/cerb.v14i1.3767

Vasu AE (2008) Studies on the removal of rhodamine B and malachite green from aqueous solutions by activated carbon. E J Chem 5:844-852. https://doi.org/10.1155/2008/271615

Wang Y, Chu W (2011) Adsorption and removal of a xanthene dye from aqueous solution using two solid wastes as adsorbents. Ind Eng Chem Res 50:8734-8741. https://doi.org/10.1021/ie1024497

Weber WJ, Morris JC (1962) Kinetics of adsorption on carbon from solution. J Sanit Eng Div ASCE 89:31-59

Wilhelm P, Stephan D (2007) Photodegradation of rhodamine B in aqueous solution via $\mathrm{SiO}_{2} @ \mathrm{TiO}_{2}$ nano-spheres. J Photochem Photobiol, A 185:19-25. https://doi.org/10.1016/j.jphotochem .2006 .05 .003

Wu FC, Tseng RI, Jung RS (2001) Kinetic modeling of liquid-phase adsorption of reactive dyes and metals on chitosan. Water Res 35:613-618. https://doi.org/10.1016/S0043-1354(00)00307-9

Xiong C, Jia Q, Chen X et al (2013) Optimization of polyacrylonitrile2 -aminothiazole resin synthesis, characterization, and its adsorption performance and mechanism for removal of $\mathrm{Hg}$ (II) from aqueous solutions. Ind Eng Chem Res. https://doi.org/10.1021/ ie3033312

Yadav SK, Singh DK, Sinha S (2013) Adsorption study of lead(II) onto xanthated date palm trunk: kinetics, isotherm and mechanism. Desalin Water Treat. https://doi.org/10.1080/19443 994.2013.792142

Zhang Z, O'Hara IM, Kent GA, Doherty WOS (2013) Comparative study on adsorption of two cationic dyes by milled sugarcane bagasse, Indust. Crops Prod 42:41-49

Publisher's Note Springer Nature remains neutral with regard to jurisdictional claims in published maps and institutional affiliations. 